\title{
PERBANDINGAN METODE EKSTRAKSI EKSTRAK UMBI BAWANG RAMBUT (Allium chinense G.Don.) MENGGUNAKAN PELARUT ETANOL 70\% TERHADAP RENDEMEN DAN SKRINING FITOKIMIA
}

\author{
Supomo ${ }^{1}$, Husnul Warnida ${ }^{2}$, Bagus Moch Sahid ${ }^{3}$ \\ 1,2,3 Akademi Farmasi Samarinda \\ Jl. Brig Jend A. Wahab Syahranie, Samarinda, Kaltim 75124 \\ Email korespendensi: fahmipomo@gmail.com,
}

\begin{abstract}
ABSTRAK
Bawang rambut (Allium chinense G.Don.) merupakan tanaman yang mengandung senyawa bioaktif seperti alkaloid, flavonoid dan saponin. Rendemen suatu ekstrak dapat dipengaruhi oleh metode ekstraksi yang digunakan. Penelitian ini bertujuan untuk mengetahui pengaruh metode ekstraksi maserasi dan digesti terhadap hasil rendemen dan identifikasi senyawa metabolit sekunder pada ekstrak umbi bawang rambut. Penelitian yang dilakukan adalah penelitian eksperimental. Sampel yang digunakan adalah bawang rambut yang diperoleh di Kota Bangun Kalimantan Timur, diekstraksi dengan 2 metode ekstraksi yaitu metode maserasi dan digesti menggunakan pelarut etanol $70 \%$ dan dilakukan sebanyak 3 kali replikasi. Identifikasi senyawa metabolit sekunder dilakukan dengan skrining fitokimia meliputi uji alkaloid, flavonoid, saponin, tanin, dan steroid. Data pengujian diolah dengan analisis statistik. Hasil penelitian rendemen dengan 3 kali replikasi dari metode digesti diperoleh sebesar 20,02 gram, 19,03 gram, dan 19,17 gram. Sedangkan metode maserasi diperoleh sebesar 12,38 gram, 12,45 gram, dan 15,91 gram. Sehingga terdapat perbedaan antara rendemen hasil metode digesti dan metode maserasi. Berdasarkan pengujian skrining fitokimia menunjukkan bahwa ekstrak kental umbi bawang rambut mengandung senyawa alkaloid, flavonoid dan saponin.
\end{abstract}

Kata kunci : Digesti, Maserasi, Allium chinense, Skrining Fitokimia, Rendemen 


\section{ABSTRACT}

Allium chinense are plants that contain bioactive compounds such as alkaloids, flavonoids, and saponins. The rendement of an extract may be affected by the extraction mentod used. This study aims to determine the effect of maseration and digestion extraction method on rendemen and identification of secondary metabolite in the extract of the hair onion bulbs. Research conducted is an experimental study. The samples used were hair bulbs obtained in Kota Bangun, East Kalimantan, extracted wiyh 2 extraction methods of maceration and digestion using ethanol $70 \%$ solvent and done as much as 3 times replication. Identification of secondary metabolite compounds was performed by phytochemical screening including test of alkaloids, flavonoids, saponins, tannins, and steroids. From the test data is processed by statistical analysis. The result of rendement with 3 times replikation of digesti mentod obtained by 20,02 gram, 19,03 gram, and 19,17 gram. While the maseration method obtained for 12,38 grams, 12,45 grams, and 15,91 grams. So there are differences between the results of the results of digestion mentod and maseration mentod. Based on phytochemical screening tets showed that the thick extract of hair onion bulbs contain compounds alkaloids, flavonoids, and saponins.

Keywords: Digestion, Maseration, Allium chinense, Phytochemical Screening, Rendement

\section{PENDAHULUAN}

Indonesia merupakan salah satu negara tropis yang memiliki biodiversitas yang tinggi kaya akan flora dan fauna. Sebagian besar tumbuhan tersebut dapat digunakan untuk mengatasi masalah kesehatan karena bersifat alami. Secara turuntemurun masyarakat indonesia telah memanfaatkan tanaman yang berada di alam untuk memenuhi kebutuhan hidup, termasuk pemanfaatan tanaman sebagai obat-obatan (Poeloengan et al, 2006).

Salah satu tumbuhan yang banyak dimanfaatkan oleh masyarakat adalah genus Allium yang terdiri atas 280 spesies dan tersebar di seluruh dunia (Robinowitch et al, 2002).

Bawang rambut (Allium chinense G.Don.) merupakan salah satu genus Allium yang telah banyak dibudidayakan oleh masyarakat di daerah Kalimantan Timur. Bawang rambut termasuk tanaman pangan yang dikomsumsi oleh masyarakat Kalimantan Timur sebagai bumbu masakan, sayuran dan obat tradisional.

Ekstraksi merupakan proses penarikan kandungan kimia atau zat yang terdapat dalam suatu bahan yang dapat larut sehingga terpisah dari bahan yang tidak dapat larut dengan menggunakan pelarut. Beberapa metode umum yang dapat digunakan untuk ekstraksi adalah maserasi, digesti, perkolasi, sokletasi, dan refluks (Depkes RI, 2000).

Maserasi merupakan proses ekstraksi tanpa pemanasan dengan perendaman dan beberapa kali 
pengocokan atau pengadukan pada temperatur ruangan (kamar). Berdasarkan proses ekstraksi metode maserasi dapat juga dilakukan cara panas dengan modifikasi menggunakan suhu $40^{\circ} \mathrm{C}$ (Depkes RI, 2000).

Penelitian Putri, (2014), menyatakan bahwa rendemen yang dihasilkan menggunakan metode maserasi dan digesti memiliki pengaruh yang berbeda. Serta kandungan senyawa metabolit sekunder yang terdapat pada ekstrak bawang rambut adalah alkaloid, flavonoid, saponin, triterpenoid, steroid, dan minyak atsiri (Liu et al, 2014). Tetapi, penelitian tentang ekstraksi umbi bawang rambut dengan menggunakan metode digesti jarang ditemukan atau belum pernah dilakukan.

Berdasarkan latar belakang, maka dilakukan penelitian tentang pengaruh rendemen dan skrining fitokimia ekstrak umbi bawang rambut (Allium chinense G.Don) berdasarkan metode ekstraksi menggunakan pelarut etanol $70 \%$.

\section{METODOLOGI PENELITIAN}

\section{Alat Dan Bahan}

Alat-alat yang digunakan adalah beaker glass (pyrex), neraca analitik, blender, wadah kaca, gunting, gelas ukur $100 \mathrm{ml}$, maserator, hot plate, tabung reaksi dan rak tabung, cawan porselin, labu spiritus, penangas air, ayakan mesh 60, infrared thermometer, sendok tanduk, corong buchner, vacum, erlenmayer, pipet, batang pengaduk kaca, aluminium foil.

Bahan yang digunakan antara lain etanol $70 \%$, air suling, tissue, kertas saring, asam asetat anhidrat, asam klorida pekat, besi (III) klorida $1 \%$, kloroform, asam sulfat pekat, serbuk magnesium, amil alkohol, pereaksi bouchardat, pereaksi dragendorf, pereaksi meyer, pereaksi lieberman-bouchardat, ekstrak kental umbi bawang rambut (Allium chinense G.Don).

\section{Prosedur Penelitian \\ Pembuatan Simplisia}

Sampel yaitu umbi bawang rambut yang diambil dari desa Kedang Ipil Kota Bangun. Determinasi tanaman umbi bawang rambut dilakukan di Labolatorium Fisiologi Jurusan Biologi Fakultas Matematika dan Ilmu Pengetahuan Alam Universitas Mulawarman Samarinda. Bawang rambut yang telah dikumpulkan ditimbang, dicuci, ditiriskan dan diangin-anginkan sampai kering \pm 7-14 hari dan dihaluskan.

\section{Ekstraksi Dengan Metode Maserasi Dan Digesti}

Metode maserasi dilakukan dengan cara merendam serbuk simplisia ditimbang 50 gram, dimasukkan dalam wadah kaca dan ditambahkan larutan etanol $70 \%$ direndam selama 24 jam. Kemudian diaduk dengan maserator dengan kecepatan \pm 1000 rpm selama 2 jam. Hasil ekstraksi disaring menggunakan corong buchner dan vacum untuk memisahkan maserat dengan filtrat. Selanjutnya dilakukan penguapan menggunakan penangas air untuk mendapatkan ekstrak kental dan diulangi seluruh proses sebanyak 3 kali.

Sedangkan untuk digesti, sebanyak 50 gram serbuk umbi bawang 
rambut, dimasukkan dalam wadah kaca dan ditambahkan larutan etanol $70 \%$ direndam selama 24 jam. Kemudian diletakkan di atas hot plate, atur suhu $40^{\circ} \mathrm{C}$ dan ditunggu hingga suhu pada sampel mencapai $40^{\circ} \mathrm{C}$ yang diukur menggunakan infrared thermometer. Perlakuan pengadukan sampel dilakukan menggunakan maserator dengan kecepatan \pm 1000 rpm selama 2 jam. Hasil ekstraksi disaring menggunakan corong buchner dan vacum untuk memisahkan maserat dengan filtrat. Selanjutnya dilakukan penguapan menggunakan penangas air untuk mendapatkan ekstrak kental dan diulangi seluruh proses sebanyak 3 kali.

\section{Identifikasi Skrining Fitokimia}

Ekstrak kental etanol selanjutnya diambil secukupnya dan dilarutkan dalam $20 \mathrm{ml}$ etanol untuk pengujian skrining fitokimia.

\section{Alkaloid}

Ekstrak etanol sebanyak $1 \mathrm{~mL}$ ditambahkan $2 \mathrm{~mL}$ HCL $2 \mathrm{~N}$ dan dikocok. Campuran selanjutnya dibagi dalam 3 tabung berbeda. Masing-masing tabung ditetesi pelarut Mayer pada tabung pertama, tabung kedua ditetesi 1 tetes pelarut Dragendorf, dan 1 tetes pelarut Bouchardat pada tabung ketiga. Adanya senyawa alkaloid jika pada penambahan pelarut Mayer terbentuk endapan kuning, pada penambahan pelarut Dragendorf terbentuk endapan merah dan penambahan pelarut Bouchardat terbentuk endapan coklat. Hasil positif mengandung senyawa alkaloid jika terjadi endapan atau paling sedikit dua dari tiga percobaan diatas (Harbone, 1987).

\section{Flavonoid}

Ekstrak etanol sebanyak $1 \mathrm{~mL}$ ditambahkan $3 \mathrm{~mL}$ etanol 70\%, dan dikocok, selanjutnya dipanaskan dalam penangas air dan disaring. Filtrat hasil mpenyaringan ditambahkan serbuk $\mathrm{Mg}$ sebanyak 0,1 gram serta 2 tetes $\mathrm{HCl}$ pekat dan amil alkohol. Uji positif flavonoid ditandai dengan adanya warna merah, kuning hingga jingga pada lapisan amil alkohol (Harbone, 1987).

\section{Saponin}

Ekstrak etanol sebanyak $1 \mathrm{~mL}$ dicampur $2 \mathrm{~mL}$ aquadest dan dikocok selama 1 menit. Kemudian ditambahkan 2 tetes $\mathrm{HCl}$. Hasil positif adanya senyawa saponin jika terbentuk busa tidak hilang (Harbone, 1987).

\section{Tanin}

Ekstrak etanol sebanyak $1 \mathrm{~mL}$ ditambahkan 5 bagian air panas dimasukkan ke dalam tabung reaksi, lalu ditambahkan 2 tetes $\mathrm{FeCl}_{3}$ 1\%. Kemudian diamati perubahan jika terbentuk warna biru kehitaman atau biru violet maka positif adanya senyawa tanin (Harbone, 1987).

\section{Steroid}

Ekstrak etanol sebanyak $1 \mathrm{~mL}$, tambahkan $10 \mathrm{ml}$ N-Heksan, lalu diuapkan dicawan menguap. kemudian ditambahkan 6 tetes asam asetat anhidrat dan 2 tetes 
asam sulfat pekat. Hasil uji positif mengandung senyawa steroid jika mengalami perubahan warna menjadi biru muda atau hijau (Harbone, 1987).

\section{HASIL DAN PEMBAHASAN}

\section{Hasil Determinasi Tumbuhan}

Hasil determinasi tumbuhan di Labolatorium Anatomi dan Sistematika Tumbuhan Fakultas Matematika dan Ilmu Pengetahuan Alam Universitas Mulawarman, menunjukkan bahwa sampel adalah spesies Allium chinense G.Don, famili Liliaceae.

\section{Pembuatan Simplisia}

Pembuatan simplisia pada penelitian ini digunakan sebanyak 1800 gram selanjutnya dilakukan proses sortasi, pencucian, pengeringan dan penghalusan sehingga diperoleh 312 gram serbuk kering umbi bawang rambut, sehingga diketahui susut pengeringannya sebesar 82,66 \%. Proses sortasi basah dengan memisahkan bagian umbinya dan dicuci untuk menghilangkan kotoran asing yang tercampur, umbi yang telah dibersihkan kemudian dirajang. Perajangan dilakukan untuk mempermudah proses pengeringan. Umbi bawang rambut dikeringkan dengan cara diangin-anginkan selama 14 hari dengan tujuan untuk mengilangkan kandungan air pada simpisia, sehingga didapatkan simplisia yang tidak mudah rusak karena air mudah ditumbuhi oleh jamur atau kapang, agar simplisia tahan dalam penyimpanan pada jangka waktu yang lama (Depkes RI, 1987). Umbi bawang rambut yang telah dikeringkan selanjutnya dihaluskan dengan blender dan diayak menggunakan mesh 60 . Tujuan pengayakan mengunakan mesh 60 untuk memperbesar luas permukaan sampel sehingga penarikan senyawa kimia yang terkandung lebih mudah dilewati pelarut pada proses ekstraksi (Akmal, 2014). Serbuk simplisia selanjutnya disimpan dalam wadah kering dan terlindung dari cahaya untuk mencegah kerusakn dan mutu simplisia tetap terjaga.

\section{Ekstraksi Umbi Bawang Rambut (Allium chinense G.Don.) Dengan Maserasi dan Digesti}

Serbuk simplisia ditimbang 50 gram, dimasukkan dalam wadah kaca dan ditambahkan larutan etanol 70\% direndam selama 24 jam. Kemudian diaduk dengan maserator dengan kecepatan \pm 1000 rpm selama 2 jam. Hasil ekstrtaksi disaring menggunakan corong buchner dan vacum untuk memisahkan maserat dengan filtrat. Selanjutnya dilakukan penguapan menggunakan penangas air untuk mendapatkan ekstrak kental dan diulangi seluruh proses sebanyak 3 kali.

Metode maserasi dipilih karena perlakuannya sederhana tidak memerlukan pemanasan sehingga dapat mencegah kandungan senyawa metabolit sekunder yang tidak tahan terhadap suhu tinggi pada proses ekstraksi. Metode ini juga sangat efektif karena sifat bahan dari bawang rambut 
yang tidak tahan pada metode ekstraksi suhu tinggi (Naibaho, 2015).

Sedangkan perlakuan metode digesti, sebanyak 50 gram serbuk umbi bawang rambut, dimasukkan dalam wadah kaca dan ditambahkan larutan etanol $70 \%$ direndam selama 24 jam. Kemudian diletakkan di atas hot plate, atur suhu $40^{\circ} \mathrm{C}$ dan ditunggu hingga suhu pada sampel mencapai $40^{\circ} \mathrm{C}$ yang diukur menggunakan infrared thermometer. Perlakuan pengadukan sampel dilakukan menggunakan maserator dengan kecepatan \pm 1000 rpm selama 2 jam. Hasil ekstrtaksi disaring menggunakan corong buchner dan vacum untuk memisahkan maserat dengan filtrat. Selanjutnya dilakukan penguapan menggunakan penangas air untuk mendapatkan ekstrak kental dan diulangi seluruh proses sebanyak 3 kali.

Pemilihan metode digesti karena aman dilakukan untuk mengekstraksi senyawa flavonoid karena Berdasarkan sifat golongan senyawa flavonoid yang tidak tahan pemanasan suhu tinggi dan mudah teroksidasi (Siregar et al, 2015).

\section{Perbandingan Rendemen}

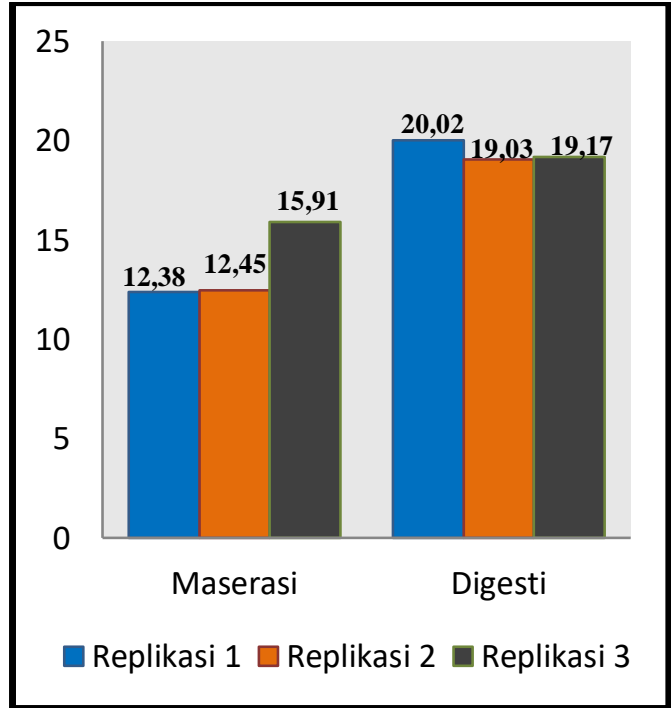

\section{Gambar 1. Grafik Perbandingan}

Berdasarkan gambar 1, hasil rendemen yang diperoleh dari metode digesti secara berturut-turut yaitu 20,02 gram, 19,03 gram, dan 19,17 gram. Serta hasil rendemen yang diperoleh dari metode maserasi secara berturutturut yaitu 12,38 gram, 12,45 gram, dan 15,91 gram. Sehingga hasil perolehan data diatas menunjukkan adanya perbedaan hasil rendemen antara metode digesti dan metode maserasi. Berdasarkan hasil uji statistik menunjukkan nilai sig $0,008<0,05$ yang berarti bahwa terdapat perbedaan signifikan hasil rendemen antara metode digesti dan maserasi. Perbedaan hasil rendemen antara metode maserasi dan metode digesti dipengaruhi oleh faktor suhu. Ekstraksi metode maserasi dilakukan pada suhu ruang $\left(15^{\circ} \mathrm{C}-30^{\circ} \mathrm{C}\right)$ sedangkan metode digesti dilakukan pada suhu hangat $\left(40^{\circ} \mathrm{C}\right)$. Faktor suhu dan dapat meningkatkan laju perpindahan senyawa semakin sering terjadi antara pelarut dengan kontak zat terlarut (solut) dalam sampel sehingga diperoleh ekstrak yang banyak (Nurhasnawati H, 2017).

Tabel 1. Data Hasil Rendemen Metode Maserasi dan Digesti

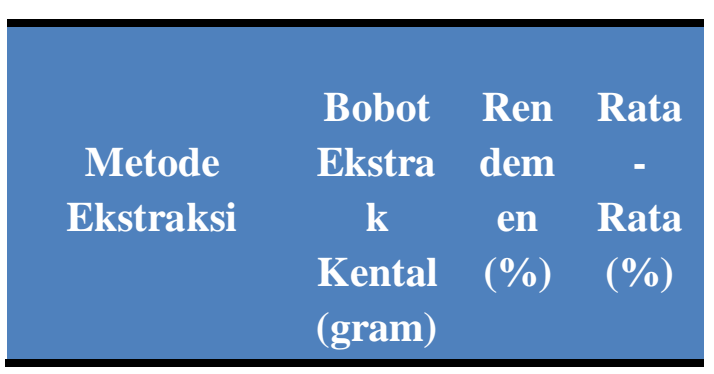




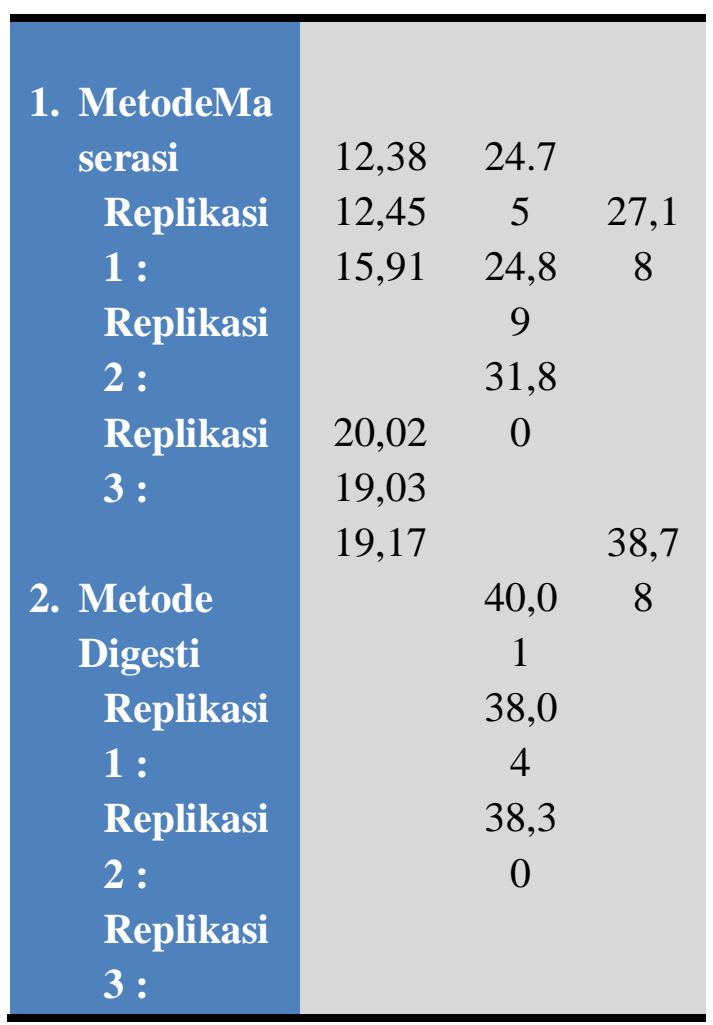

Berdasarkan tabel 1, perolehan rendemen dari metode digesti dengan perlakuan 3 kali pengulangan menghasilkan persentase lebih besar yaitu 40,01 \%, 38,04\%, dan 38,30\%. Sedangkan perolehan rendemen dari metode maserasi memiliki persentase lebih kecil yaitu 24,75\%, 24,89\%, dan $31,80 \%$. Sehingga hasil data yang diperoleh terdapat pengaruh antara metode ekstraksi umbi bawang rambut terhadap hasil rendemen dengan metode ekstraksi yang berbeda. Perbedaan hasil rendemen diduga karena suhu. Pengaruh suhu pada proses ekstraksi dapat menyebabkan terjadinya permeabilitas sel dimana ketebalan dinding sel akan berkurang akibat adanya tekanan dari dalam maupun luar sel. Kemudian dinding sel akan mengalami kerusakan dan pecah akibat pemanasan. Sehingga kandungan senyawa yang terdapat pada simplisia akan tertarik keluar bersama pelarut yang digunakan (Riyani et al, 2018).

\section{Skirining Fitokimia}

Skrining fitokimia merupakan pemeriksaan kandungan senyawa kimia secara kualitatif untuk mengetahui golongan senyawa yang terkandung suatu tanaman. Pengujian senyawa metabolit sekunder tersebut meliputi uji alkaloid, flavonoid, saponin, tanin dan steroid. Hasil skrining fitokimia dapat dilihat pada tabel 2 .

Tabel 2.Hasil skrining fitokimia umbi bawang rambut

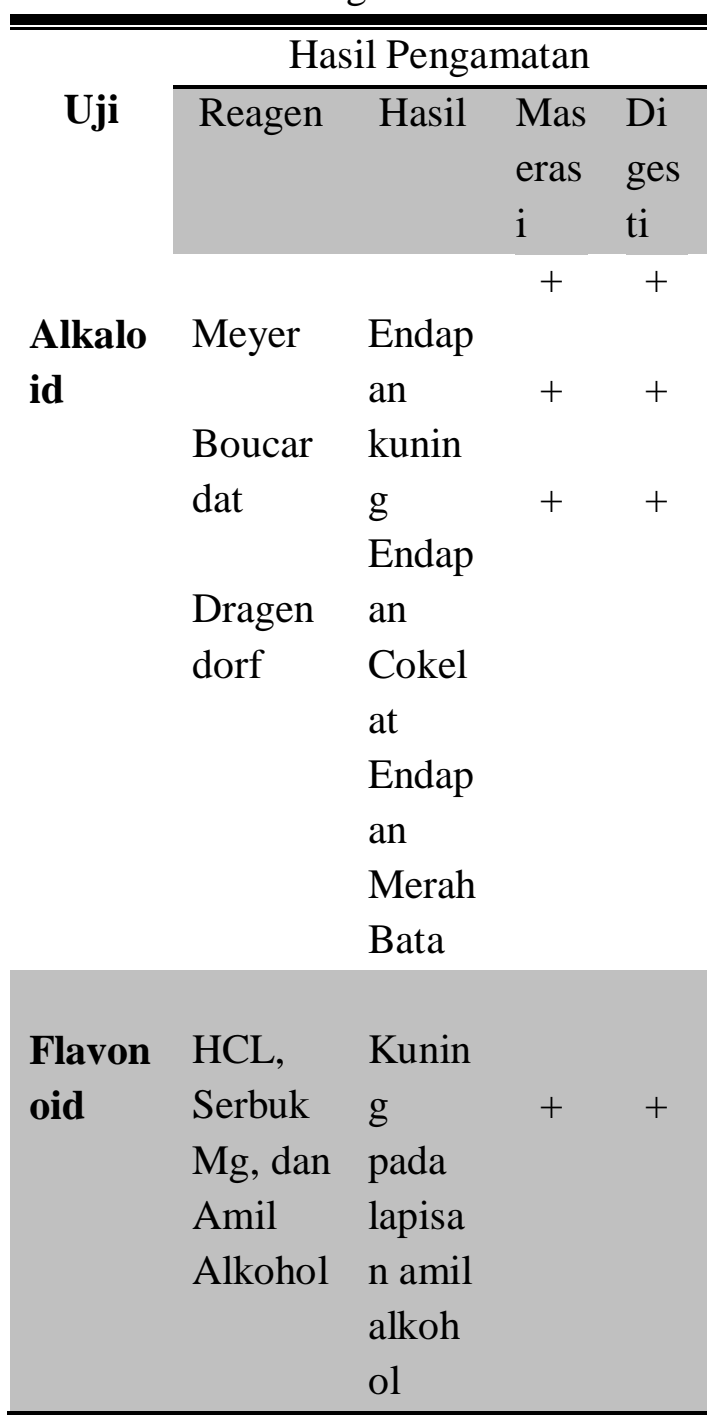




\begin{tabular}{lllll}
\hline Saponi & $\begin{array}{l}\text { Aquade } \\
\text { n }\end{array}$ & $\begin{array}{l}\text { Busa } \\
\text { st dan }\end{array}$ & + & + \\
& HCL & hilang & & \\
& & & & \\
Steroi & N- & Laruta & & \\
d & Heksan, & $\mathrm{n}$ & - & - \\
& Asam & Cokla & & \\
& Asetat & $\mathrm{t}$ & \\
& Anhidra & Keku & \\
& $\mathrm{t}$ dan & ninga & \\
& Asam & $\mathrm{n}$ & \\
& Sulfat & & \\
& Pekat & & \\
Tanin & Besi(III & Laruta & - \\
& ) & $\mathrm{n}$ \\
& klorida & kunin & \\
& $1 \%$ & $\mathrm{~g}$ \\
\hline \hline
\end{tabular}

Keterangan :

$+\quad$ : Positif mengandung metabolit sekunder

- $\quad$ : Negatif mengandung metabolit sekunder

Berdasarkan tabel 2 hasil uji skrining fitokimia dari metode maserasi dan metode digesti umbi bawang rambut adalah sama, positif mengandung senyawa alkaloid, flavonoid dan saponin. Senyawa alkaloid merupakan senyawa yang bersifat basa karena mengandung atom nitrogen. Pengujian senyawa alkaloid dilakukan dengan penambahan larutan asam klorida dan air. Tujuan penambahan asam klorida dan air untuk menjenuhkan larutan karena alkaloid bersifat basa, sehingga memerlukan larutan yang mengandung asam (Harbone, 1987). Hasil identifikasi senyawa alkaloid dengan penambahan reagen Mayer, Bouchardat, dan Dragendorf menunjukkan hasil positif dengan terbentuknya endapan berwarna kuning, coklat, dan merah bata pada masing-masing reagen. Endapan terbentuk karena senyawa nitrogen berikatan dengan ion $\mathrm{K}^{+}$yang terdapat pada masing-masing reagen (Simaremare, 2014). Perbedaan warna endapan setiap penambahan reagen dikarenakan adanya pergantian ligan berupa logam yang terdapat pada reagen Mayer, Bouchardat, dan Dragendorf (Wardana et al, 2016).

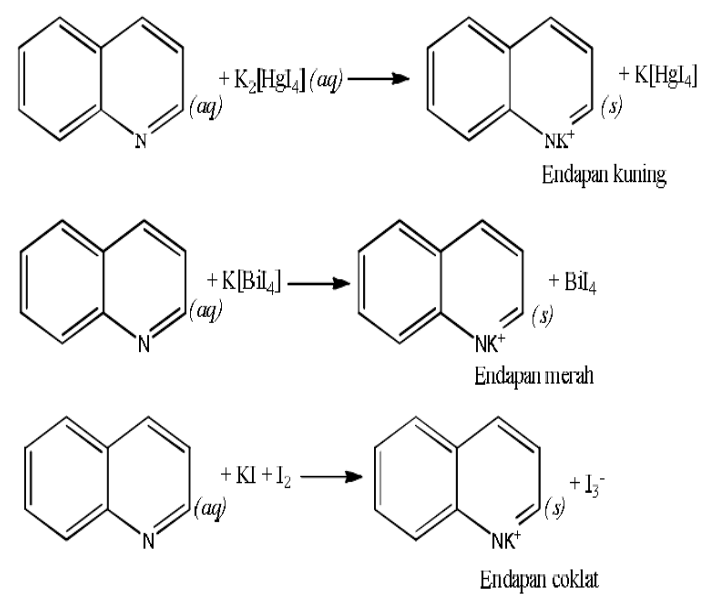

Gambar 2. Reaksi Uji Fitokimia Alkaloid (Nafisah et al, 2014)

Saponin merupakan senyawa yang mempunyai gugus hidrofilik dan hidrofob (Simaremare, 2014). Hasil identifikasi senyawa saponin dapat membentuk adanya busa karena memiliki sifat fisik yang mudah terhidrolisis dalam air sehingga menimbulkan busa ketika dikocok (Rustina, 2016). Prinsip uji saponin adalah reaksi hidrolisis senyawa saponin menjadi aglikon (senyawa bukan gula) dan glikon (senyawa gula) yang ditandai terbentuknya busa yang stabil (Wardana et al, 2016). 


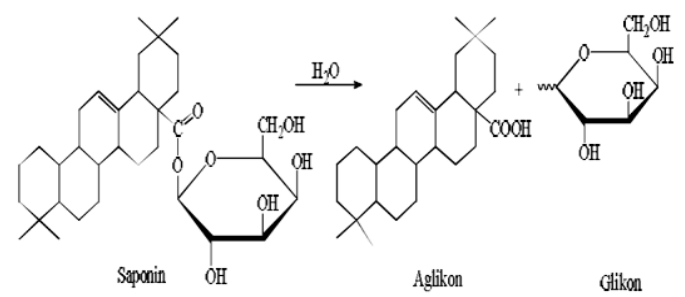

Gambar 3. Reaksi Uji Fitoimia Saponin (Marliana, 2005)

Sedangkan pada pengujian senyawa flavonoid terbentuknya warna kuning pada lapisan amil alkohol diduga karena reduksi oleh gas hidrogen setelah penambahan asam klorida pekat dan serbuk magnesium menjadi aglikonnya (Robinson, 1995).

Selanjutnya senyawa hasil reduksi akan membentuk senyawa komplek dengan magnesium membentuk warna kuning (Wardana et al, 2016).

$\mathrm{Mg}(\mathrm{s})+2 \mathrm{HCl}(\mathrm{aq}) \rightarrow \mathrm{MgCl}_{2}(\mathrm{aq})+\mathrm{H}_{2}(\mathrm{~g})$

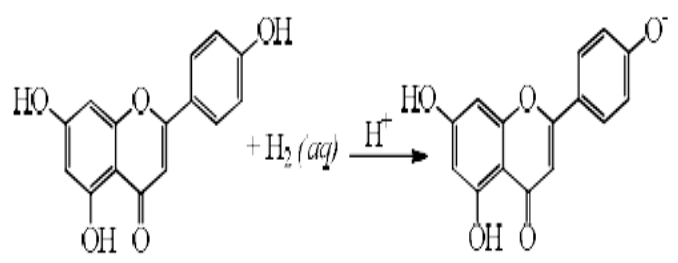

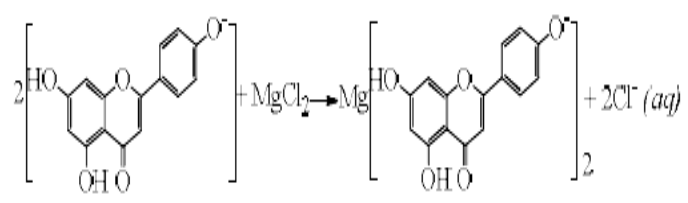

Gambar 4. Reaksi Uji Fitokimia Flavonoid (Andersen et al, 2006)

Metabolit sekunder berupa alkaloid dapat berkhasiat sebagai anti diare, antidiabetes, antimikroba, dan antimalaria, akan tetapi beberapa senyawa golongan alkaloid dapat bersifat racun (Ningrum et al, 2016).
Saponin dapat berkhasiat menurunkan tegangan permukaan sehingga dapat menghambat pertumbuhan jamur (Khotimah K, 2016). Flavonoid merupakan senyawa turunan fenol yang berkhasiat menurunkan kolestrol dan lipid karena bersifat antibakteri (Rustina, 2016). Senyawa flavonoid juga berpotensi sebagai antioksidan karena strukturnya mengandung gugus hidroksil yang dapat mendonorkan atom hidrogennya kepada radikal bebas (Supomo dkk, 2017).

\section{KESIMPULAN}

Berdasarkan hasil penelitian yang diperoleh dapat disimpulkan bahwa terdapat perbedaan signifikan antara hasil rendemen metode digesti lebih besar dari metode maserasi yaitu $38,78 \%<27,14 \%$. Serta senyawa metabolit sekunder yang terdapat pada tumbuhan umbi bawang rambut dari metode maserasi dan digesti adalah sama, positif mengandung alkaloid, flavonoid dan saponin.

\section{Ucapan Terimakasih}

Ucapan terimakasih kepada Yayasan Kagama Kalimantan Timur pada Akademi Farmasi Samarinda, yang telah memberikan fasilitas peralatan dan Laboratorium selama penelitian.

\section{DAFTAR PUSTAKA}

Andersen, Oyvind, and Merkham, Kenneth R. 2006. Flavonoids Chemistry, Biochemistry and Aplications. New York: CRC Press Taylor and Francis Group. Hal: 143.

Departemen Kesehatan RI. 1987. 
Analisis Obat Tradisional. Jakarta: Depkes RI. Hal: 8.

Departemen Kesehatan RI. 2000. Parameter Standar Umum Ekstrak Tumbuhan Obat. Jakarta: Depkes RI. Hal 3-14.

Fathurrachman, Denny Akmal. 2014. "Pengaruh Konsentrasi Pelarut Terhadap Aktivitas Antioksidan Ekstrak Etanol Daun Sirsak (Annona mucirata Linn) dengan Metode Perendaman Radikal Bebas DPPH". Skripsi. Jakarta: Universitas Islam Negeri Syarif hidayatullah. Hal: 35-37.

Harbone, J.B. 1987. Metode Fitokimia Penuntun Cara Modern Menganalisis Tumbuhan. Bandung: ITB Press. Hal: 522531,647 .

Khotimah, Khusnul. 2016. "Skrining Fitokimia dan Identifikasi Metabolit Sekunder Senyawa Karpain Pada Ekstrak Metanol Daun (Carica pubescens Lenne \& K.Koch) dengan LC/MS”. Skripsi. Malang: Universitas Islam Negeri Malang. Hal: 39-41.

Liu, X.C., Lu, X.N., Liu, Q.Z., Liu, Z.L. 2014."Evalution of insecticidal activity of the essential oil of Allium chinense G.Don and its major constituens against Liposcelis bostrychophila Badonnel". Journal of AsiaPacific Entomology. (17): 853856.
Marliana Dewi Soerya, Suryanti Venty, Suyono. 2005. Skrining Fitokimia dan Analisis kromatografi Lapis Tipis Komponen Kimia Buah Labu Siam (Sechium edule Jacq. Swartz.) dalam Ekstrak Etanol. Surakarta: Jurnal Biofarmasi. Vol 3(1).Jurusan Kimia FMIPA, Universitas Sebelas Maret. Hal: 26-31.

Nafisah, Minhatus, Tukiran, Suyatno, Hidayati, dan Nurul. 2014.'Uji Skrining Fitokimia Pada Ekstrak N-Heksan, Kloroform, Dan Metanol Dari Tanaman Patikan Kebo (Euphorbiae Hirtae)". Prosiding seminar Nasional Kimia Universitas Negeri Surabaya. (1): Hal: 279-286.

Nigrum Retno, Purwanti Elly, Sukarsono. 2016. "Identifikasi Senyawa Alkaloid dari Batang Karamunting (Rhodomyrtus tomentosa) Sebagai Bahan Ajar Biologi”. Jurnal Pendidikan Biologi Indonesia. Vol. (2)3: 231.

Nurhasnawati Henny., Sukarmi S, dan Handayani F. 2017. "Perbandingan Metode Ekstraksi Maserasi Dan Sokletasi Terhadap Aktivitas Antioksidan Ekstrak Etanol Daun Jambu BOL (Syzygium malaccense L.)". Jurnal Ilmiah Manutung. Vol. (3)1: 91-95.

Putri, Dea Alvicha. 2014. "Pengaruh metode ekstraksi dan konsentrasi 
terhadap aktivitas jahe merah (Zingiber officinale var rubrum) sebagai antibakteri Escherchia coli ". Skripsi. Bengkulu: Universitas Bengkulu. Hal: 14-32.

Poelengan, Masniari Chairul., Iyep, Komala., Siti, Salmah., Susan, M.N. 2006. Aktivitas Antimikroba dan fitokimia dari beberapa tanaman obat. Bogor: Institut Pertanian Bogor. Hal: 974-978.

Rabinowtch, H.D., Kamenetsky, R. 2002. 17 Shallot (Allium cepa, Aggregatum Group). Allium Crop Science: Recent Advances. New York: CABI Publishing: 4.

Riyani Dhea Widya Wijati., Rohadi., Pratiwi Ery. 2018. "Variasi Suhu Maserasi Terhadap Rendemen dan Karakteritik Minyak Atsiri Jahe Emprit". Journal E-publikasi. Semarang: Universitas Negeri Semarang. Hal: 6.

Rustina. 2016. “ Uji Aktivitas Antioksidan dan Antibakteri Ekstrak Etil Asetat Labu Kuning (Cucuma moschata Duch.Poir)". Skripsi. Yogyakarta: Universitas Muhammadiyah Yogyakarta. Hal: 36-40.

Robinson, T. 1995. Kandungan Senyawa Organik Tumbuhan Tinggi. Bandung: Institut Teknologi Bandung. Hal: 47-53

Simaremare Eva Susanti. 2014. "Skrining Fitokimia Ekstrak
Etanol Daun Gatal (Laportea decumana (Roxb.) Wedd)". Jurnal Ilmiah Farmasi. Vol. (11)1: 103-104.

Siregar Tagor Marsillan, Eveline, Jaya Felita Anthony. 2015. "Kajian Aktivitas dan Stabilitas Antioksidan Ekstrak Kasar Bawang Daun (Allium fistulosum L.). Kajian Ilmiah. Vol. (6): 41.

Supomo, Syamsul, Eka Siswanto, Manurung, Nurani. 2017. 'Uji Aktivitas Antioksidan Ekstrak Etanol Umbi Bawang Rambut (Allium chinense G.Don) Dengan Penagkal Radikal DPPH (1,1Difenil-2-Pikrilhidrazil)". Jurnal Ilmiah Sehat Bebaya. Vol. (2)1: 165-166.

Voigt, R. 1995. Buku Pelajaran Teknologi Farmasi. Yogyakarta: Gadja Mada University Press. Hal: 557-558, 605.

Wardana Andika Pramudya, Tukiran. 2016. "Skrining Fitokimia dan Aktivitas Antioksidan Ekstrak Kloroform Tumbuhan Gowok (Syzygium polycephalum)". Prosiding Seminar Nasional Kimia. Vol. (1):4-5 